\title{
Analysis of Growth and Yield Parameters for Four Cowpea Varieties in Kirimiro Ecological Conditions
}

\author{
BANDUSHUBWENGE Denis $*^{1}$, KWIZERA Chantal ${ }^{2}$, MBONIHANKUYE Cyrille ${ }^{3}$ \\ ${ }^{1}$ University of Burundi, Faculty of Agriculture and Bio Engineering, Department of vegetal productions \\ Sciences, B.P 2940 Bujumbura, Burundi \\ ${ }^{2}$ University of Burundi, Faculty of Agriculture and Bio Engineering, Department of Environment Sciences \\ and Technologies, B.P 2940 Bujumbura, Burundi \\ ${ }^{3}$ Agronomic Sciences Institute of Burundi (ISABU)
}

\begin{abstract}
Cowpea (Vigna unguiculata L.Walp) is a grain legume and a food major importance for millions of people, especially in less developed countries. It is not only rich in nutrients, but also in nutraceuticals such as dietary fibre, antioxidants and polyunsaturated fatty acids and polyphenols. An experiment was carried out in three blocks completely randomized at Rukoba hill of Kirimiro region to analyse the growth and yield parameters of four cowpea varieties (Local, Katumani, Rurandaranda and Fahari) to assess the variety which is more adapted to the ecological conditions of the region. The studied parameters were: leaves number, leaf length and width, plant height, pods number per plant, leaf area, grains number per pod, plant height at pods formation and yield. The outcomes showed a significant increase in leaf length and width per plant for the Rurandarada variety than the local and other varieties. Moreover, this variety recorded significantly enhanced leaf area and an effectively improved plant height. Furthermore, rurandarada variety recorded a noteworthy increase in leaves number and has significantly improved yield compared to others. The study highlighted rurandarara variety as the most adapted variety. This suggested that rurandaranda could be considered as a variety that could be cultivated in the area for the promotion of food security and the health of the population.
\end{abstract}

Keywords: Growth Parameter, Yield parameters, Local cowpea variety, Katumani cowpea variety, Rurandaranda cowpea variety, Fahari cowpea variety, kirimiro region.

\section{INTRODUCTION}

Cowpea (Vigna unguiculata) is grain legume originated in the Africa continent with large economic and social importance in the developing world. It is a food major importance for millions of people, especially in less developed countries of the tropics, being the major source of protein and carbohydrate dietary of the large part the world population. Cowpea is not only rich in nutrients, but also nutraceuticals such as dietary fibre, antioxidants and polyunsaturated fatty acids and polyphenols ${ }^{[1-2]}$. Furthermore, It was reported that Cowpea leaves and green pods are consumed as vegetable and the dried grain is used in many different food preparations ${ }^{[3-4]}$. Moreover, it is a major source of protein and a cheap source of quality protein for both rural and urban dwellers in Africa ${ }^{[5-6]}$. Cowpea leaves protein content is range from 27 to $43 \%$ and protein concentration of the dry grain from 21 to $33 \%$ ${ }^{[7-8]}$. Cowpea leaves and green pods are consumed as vegetable and the dried grain is used in many different food preparations. Okonya and Maass (2014) reported that Cowpea leaves contain important nutrients including vitamins and minerals that can improve the nutritional status of individuals and households with proper utilization ${ }^{[9]}$. As reported by foregoing research, Cowpea is rich in vitamin $\mathrm{A}$ and $\mathrm{C}^{[10]}$ which are indispensable to the maintenance of various functions of physiological importance such as muscle contractility, nerve function, blood coagulation, digestive processes and acid-base balance ${ }^{[11]}$. Furthermore, it has higher content of micronutrients, nutraceuticals, and antioxidants (alpha tocopherols, flavonoids, lycopene, and anticancer agents) ${ }^{[12]}$. Asare et al. (2013) highlighted appreciable amount of thiamin, riboflavin, niacin, vitamin B6 and pantothenic acid in cowpea as well as small amount of foliate ${ }^{[10]}$. Likewise, they affirmed content in potassium, calcium, magnesium, phosphorus, iron, sodium, zinc, copper, manganese and selenium in cowpea meaning an appropriate intake of micro minerals necessary for human organism 
to meet its metabolic needs, and hence avoid a wide range of associated health problems ${ }^{[14-15]}$. Widely consumed in many countries, cowpea is one of the key food sources in the arid and semi-arid parts with excellent nutritionnal and nutraceutical properties [16-17], and tropical parts of Asia, Oceania,southern Europe, Africa, southern United States and Central and South America ${ }^{[18]}$. It is truly a multifunctional crop, providing food for man and livestock, serving as a valuable and dependable revenue-generating commodity for farmers and grain traders ${ }^{[18-19-20]}$. Cowpea is also an important component of the traditional cropping systems because it fixes atmospheric nitrogen and contributes to soil fertility improvement particularly in smallholder farming systems where little or no fertilizer is used ${ }^{[21-22]}$. It is drought tolerant and adapted to stressful environments where many crops fail to grow well ${ }^{[23-17]}$. Cowpea has several agronomic, environmental and economic advantages, contributing to food security and maintenance of environmental ${ }^{[16-17]}$. However this crop is not yet well domesticated in Burundi due to lack of suitable varieties, whence this study has been undertaken using four cowpea varieties to appraise the better which is more adapted and productive in kirimiro, one of burundi natural regions.

\section{MATERIALS AND METHODS}

\subsection{Site description and soil properties}

The experimentation site was located in kirimiro region at Rukoba hill of Gitega province. The main soils types in kirimiro are vertisols and ferralisols ${ }^{[24]}$, while at Rukoba hill the soil is hydro-xeroferralisol developed on a schistous material, desaturated in bases and rich in exchangeable aluminum with a ph $\mathrm{H} 2 \mathrm{O}$ of 4.4 and $20.62{ }^{\circ} \mathrm{C}$ as a mean temperature ${ }^{[25]}$.

\subsection{Experiment design}

The experiment was carried out in three blocs as shown in the following photos.

Photos 1 . The three blocks for the experiments

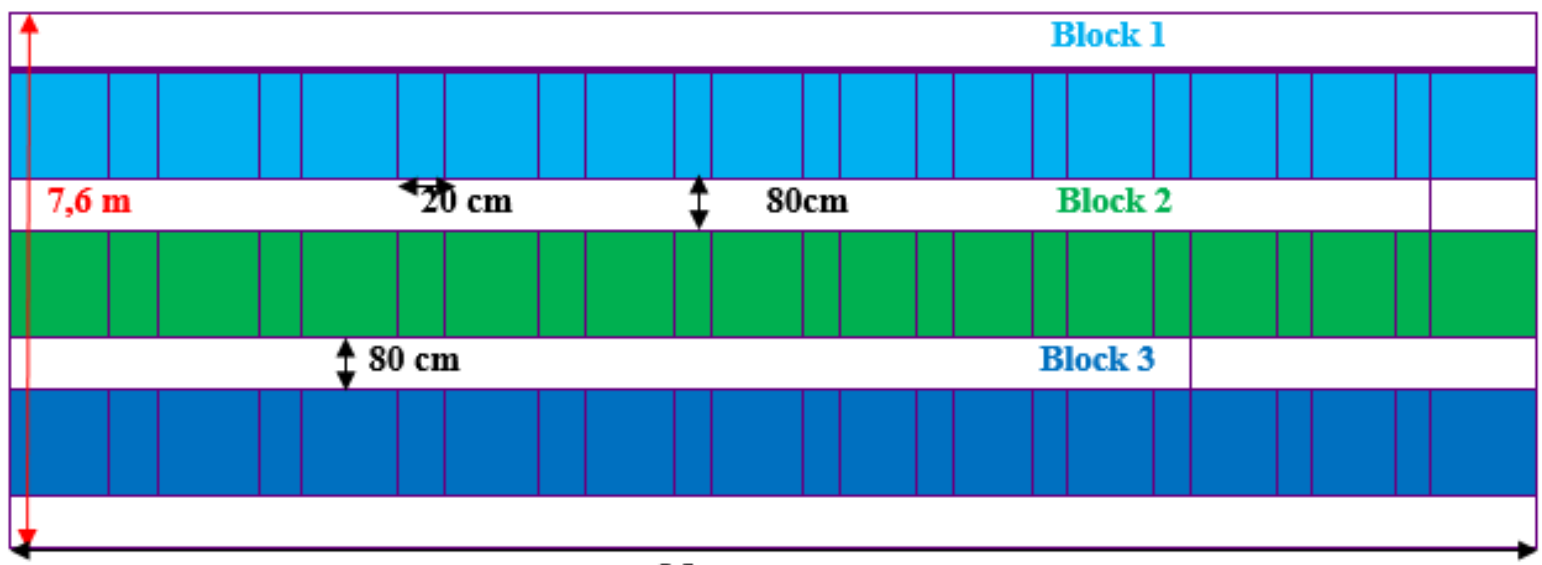

$22 \mathrm{~m}$

These blocks were completely rendomized with three replications for each. The used varieties were the local variety (L); Fahari (F), Katumani (K), and Rurandaranda (R). During experiment, lime was applied one week before sowing considering $2 \mathrm{~T} / \mathrm{ha}$ or $2000 \mathrm{~kg} / 10.000 \mathrm{~m}^{2}$, while fertilizers were applied at sowing date using the formula recommended by the Agronomic Sciences Institute of Burundi (ISABU). In general, the cowpea needs 30kg/ha of phosphorus, with 15-30-15 as formula, while for mineral fertilizers including $\mathrm{DAP}, \mathrm{KCl}$ and urea, the used formulas were respectively $18-46-0 ; 0-0-60$ and 46-0-0. The recorded parameters in this study were : plant leaf length, width and area. Likewise, plant height and leaves number were also tested, while plants height at pod formation were measured during reproductive phase. Furthermore, number of pods per plant, yield and grains number per pod were also assessed at harvest period as well as the yield. During the study, all blocks had the same agricultural management practices, while diseases and pests were controlled through insecticides and fungicides application.

\subsection{Statistical analysis}

All data were processed with Excel and Genstat. Figures were made by using Excel, while comparisons between means were conducted with $\mathrm{P}<0.05$ by using ANOVA II and the Student New Man Keuil test. 
International Journal of Advances in Scientific Research and Engineering (ijasre), Vol 6 (9), September -2020

\section{RESULTS}

Based on study results, Fahari variety did not germinate, whence it was not recorded in the figures or tables of data analysis.

\subsection{Growth parameters}

\subsubsection{Analysis of leaf width, length and leaf area}

Leaves are important site for photosynthesis, while their size and shape exhibit influence in plant quality success and light energy absorption ${ }^{[21]}$. Cowpea leaves not only represented the photosynthesis site, but is also closely related to output. Moreover leaves are key basis organ sensitive to fertilizers applied and environmental changes in evolution process. Table 1 displayed the outcomes of Cowpea varieties on leaf width, length and leaf area. During the whole growth period, maximum leaf width was recorded for Rurandaranda variety with $2.90 \mathrm{~cm}$ and significantly $(\mathrm{P}<0.05)$ differed from others. It was followed by Katumani variety which received $2.57 \mathrm{~cm}$ and did not significanlty differed to the local, variety with a minimum value of $2.39 \mathrm{~cm}$.

Table 1. Analysis of leaf length, width (cm) and leaf area $\left(\mathrm{cm}^{2}\right)$

\begin{tabular}{lccc}
\hline Varieties & Leaf width & Leaf length & Leaf area \\
\hline Local Variety & $2.39 \mathrm{a}$ & $4.72 \mathrm{a}$ & 11,28 \\
Katumani Variety & $2.57 \mathrm{a}$ & $4.94 \mathrm{~b}$ & 12,68 \\
Rurandaranda Variety & $2.90 \mathrm{~b}$ & $4.95 \mathrm{~b}$ & 14,36 \\
\hline
\end{tabular}

The same trend was observed for the plant length, where the highest value of leaf length was observed for Rurandaranda variety with $4.95 \mathrm{~cm}$ and showed significance difference comparatively to local variety. The second value was recorded for Katumani variety with $4.94 \mathrm{~cm}$ which did not differed to Rurandaranda and minimum for Local variety of $4.72 \mathrm{~cm}$. Regarding the leaf area, Rurandaranda variety $\left(14.36 \mathrm{~cm}^{2}\right)$ still recording the maximum, followed by Katunami $\left(12.68 \mathrm{~cm}^{2}\right)$, while the minimum leaf area was recorded by the Local variety $\left(11.28 \mathrm{~cm}^{2}\right)$.

\subsubsection{Plants height analysis at the first pod formation}

Cowpea is among the legume most influenced by the date of sowing, which sometimes results in a delay of pods formation, whence this study has analyze the plants height at the first pod formation. Results showed a little discrepancy regarding local and Rurandaranda varieties.

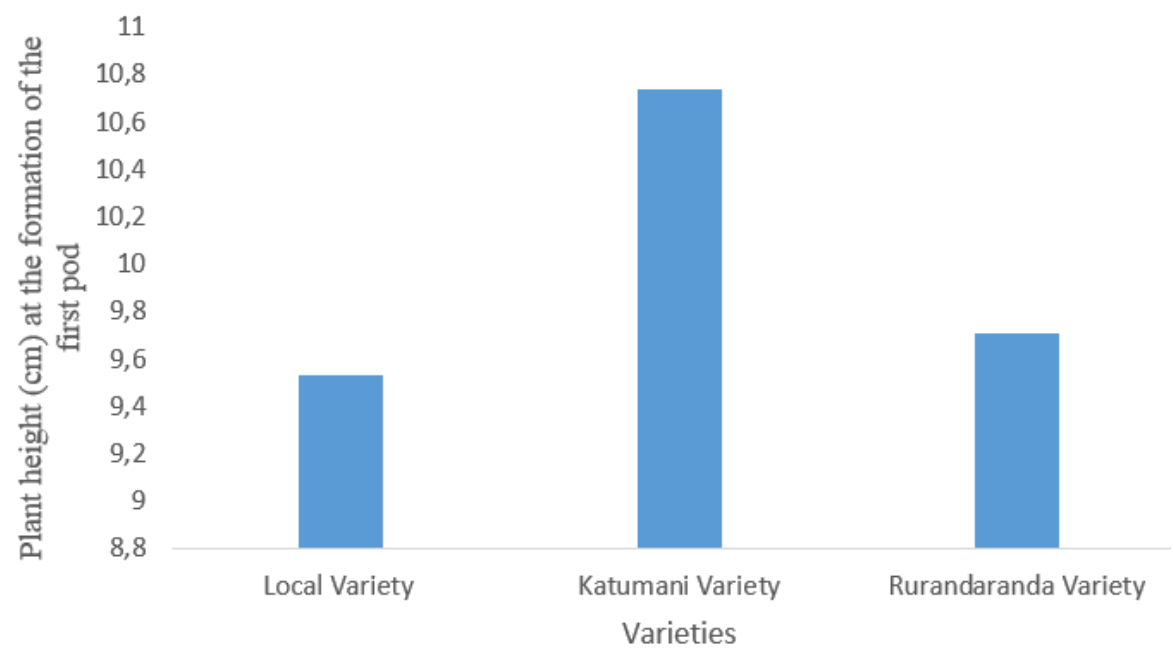

Figure1. Analysis of plants height at the first pod formation

Cleary, the first pod appeared earlier for these varieties at $9.53 \mathrm{~cm}$ and $9.71 \mathrm{~cm}$ for varieties local and Rurandaranda respectively. However the formation of the first pods was significantly late for Katumani at $10.74 \mathrm{~cm}$ height comparatively to others. 


\subsubsection{Plants height and leaves number evaluation}

The results on leaves number and plant height were summed up in table 2 below. Maximum leaves number was recorded for Rundaranda variety with 29 leaves, followed by Katumani variety of 28 leaves and both varieties significantly differed from the local which obtained the minimum value of 25 leaves. The same trend was observed for plant height where the highest plant was observed for Rurandaranda and Katumani varieties with $59.41 \mathrm{~cm}^{2}$ and $56.01 \mathrm{~cm}^{2}$ respectively. As can be seen in table 2 , the shortest plant was recorded for local variety of $46.65 \mathrm{~cm}^{2}$.

Table 2. Plants height and leaves number evaluation

\begin{tabular}{lcc}
\hline \multicolumn{1}{c}{ Varieties } & Number of leaves & Plant height $(\mathrm{cm})$ \\
\hline Local Variety & $25 \mathrm{a}$ & $46.65 \mathrm{a}$ \\
Katumani Variety & $28 \mathrm{~b}$ & $56.01 \mathrm{~b}$ \\
Rurandaranda Variety & $29 \mathrm{~b}$ & $59.41 \mathrm{~b}$ \\
\hline
\end{tabular}

However Rurandaranda and Katumani varieties did not differed significantly but showed significant difference from local veriety with $\mathrm{P}<0.05$.

\subsection{Analysis of yield, number of pods and grains}

Grains and Pods number are indicators closely related to the plant yield needing to be assessed for crop yield projection. Relate data were summed up in table 3.

Table 3. Analysis of yield, number of pods and grains

\begin{tabular}{lccc}
\hline & & Grains number per & Yield \\
Varieties & Pods number per plant & pod & (T/ha) \\
\hline Local Variety & $15 \mathrm{~b}$ & $12 \mathrm{a}$ & $867 \mathrm{a}$ \\
Katumani Variety & $18 \mathrm{~b}$ & $20 \mathrm{~b}$ & $1163 \mathrm{~b}$ \\
Rurandaranda Variety & $11 \mathrm{a}$ & $19 \mathrm{~b}$ & $1402 \mathrm{~b}$ \\
\hline
\end{tabular}

Results showed maximum pods number per plant for Katumani variety of 18 pods and it did not significantly differed from the following, the local with 15 pods. The minimum pods number per plant was recorded for Rurandaranda variety of 11 pods. Similarly, the first highest grains number was obtained for Katumani variety with 20 grains per pod. However Rundaranda recorded the second highest grains number of 19 grains, while the lowest was observed for local variety with 12 grains. Regarding the yield, the trend changes, the highest yield of 1402 tonnes/ha was recorded for Rurandaranda variety and signifantly differed from the local which recorded the lowest of 867 tonnes/ ha.

\section{DISCUSSION}

The outcomes showed maximum leaf width for $(\mathrm{R})$ variety with significant difference from others, while regarding leaf length and leaf area, it did not significantly differed to Katumani $(\mathrm{K})$ variety. Except for plants height at the first pod formation, this variety $\mathrm{K}$ did not significantly differed to $\mathrm{R}$ for other tested parameters, but both showed significant difference from local treatment (L). This significant differences in growth parameters observed among the cowpea varieties may be attributed to genotypic characters as reported by Angele et al. (2018) ${ }^{[26]}$. Likewise, it could be attributed to the effects of soil and environmental conditions on plant growth ${ }^{[7-27]}$. Regarding the yield parameters, $\mathrm{K}$ variety recorded maximum pods and grains number, while $\mathrm{R}$ occupied the last and the second places respectively. However for yield, Rurandaranda variety recorded the highest yield value comparatively to others. This may be attributed to better ability of this variety to adapt to the kirimiro ecological conditions thereby it can assimilate sufficient and adequate nutrient resulting in enhanced crop yield and growth parameters as above mentionned. Whence an enhanced food security through increased yield leading to nutritional quality of many smallholder farmers in the region.

\section{CONCLUSION}

The outcomes showed a better adaptation of Rurandaranda (R) variety comparatively to others. Although there was not significant difference between Katumani $(\mathrm{K})$ and $\mathrm{R}$ varieties, this last showed maximum mean value for almost tested growth parameters and yield. It significantly improved leaf with and length as well as the leaf area. Moreover, it showed maximum leaves number comparatively to others. Furthermore, it was realized that Rurandaranda (R) variety could significantly improve plants height 
parameter, and the cowpea yield. All this suggested Rurandaranda as the best variety with better ability to adapt to kirimiro ecological conditions.

\section{REFERENCES}

[1] Phillips RD, Watters Mc, Chinnan MS, Hung YC, Beuchat LR, Sefa-Dedeh S, Sakyi-Dawson E, Ngoddy P, Nnanyelugo D, Enwere J, Komey NS, Liu K, Mensa-Wilmot, Nnanna IA, Okeke C, Prinyawiwatkul W, Saalia FK,. Utilization of Cropea for human food. Field crop Research. 2003; $82: 193-213$

[2] Costa E. M., Nóbrega R. S. A., Martins L. V., Amaral F. H. C., Moreira F. M. S. (2011). Nodulação e produtividade de Vigna unguiculata (L.) Walp. por cepas de rizóbio em Bom Jesus, PI. Rev. Ciênc. Agron. 42 1-7. 10.1590/S1806-66902011000100001

[3] Shetty AA, Magadum S, Managanvi K. Vegetables as sources of antioxidants. Journal of Food and Nutritional Disorders. $2013 ; 2(1): 2$

[4] Baptista A, Pinho O, Pinto E, Casal S, Mota C, Ferreira IM. Characterization of protein and fat composition of seeds from common beans (Phaseolus vulgaris L.), cowpea (Vigna unguiculata L. Walp) and bambara groundnuts (Vigna subterranea L. Verdc) from Mozambique. Journal of Food Measurement and Characterization. 2017;11(2):442-450

[5]Ajeigbe H. A., Saidou A. K., Singh B. B., Hide O., Satoshi T. (2012). "Potentials for cowpea (Vigna unguiculata) for dry season grain and fodder production in the Sudan and Sahel zones of West Africa," in Innovative Research Along the Cowpea Value Chain, eds Boukar O., Coulibaly O., Fatokun C. A., Lopez K., Tamo M. [Ibadan: International Institute of Tropical Agriculture (IITA)], 189-202.

[6] Dube E., Fanadzo M. (2013). Maximizing yield benefits from dual-purpose cowpea. Food Sec. 5 769-779. 10.1007/s12571013-0307-3

[7] Ddamulira G., Santos C. A. F., Obuo P., Alanyo M., Lwanga C. K. (2015). Grain yield and protein content of Brazilian cowpea genotypes under diverse Ugandan environments. Am. J. Plant Sci. 6 2074-2084. 10.4236/ajps.2015.613208

[8] Abudulai M., Seini S. S., Haruna M., Mohammed A. M., Asante S. K. (2016). Farmer participatory pest management evaluations and variety selection in diagnostic farmer field Fora in cowpea in Ghana.Afr. J. Agric. Res. 11 1765-1771. 10.5897/AJAR2016.10887

[9]Okonya, J. S., \& Maass, B. L. (2014). Protein and iron composition of cowpea leaves: An evaluation of six cowpea varieties grown in Eastern Africa. AJFAND, 14, 9329-9340

[10] Asare AT, Agbemafle R, Adukpo GE, Diabor E, Adamtey KA. Assessment of functional properties and nutritional composition of some cowpea (Vigna unguiculata L.) genotypes in Ghana. Journal of Agricultural and Biological Science. 2013; 8(6):465-469

[11] HARDISSON A et al. Mineral composition of the banana (Musa acuminata) from the Island of Tenerife. Food Chemistry. 20017;3:153-161

[12] Shetty AA, Magadum S, Managanvi K. Vegetables as sources of antioxidants. Journal of Food and Nutritional Disorders. $2013 ; 2(1): 2$

[13] Asare A., Agbemafle R., Kingsley A., Adamtey. 2013. Assessment of functional properties and nutritional composition of some coapea (Vingna anguiculata L. ) Genotypes in Ghana. Found at: https://www.semanticscholar.org/paper/ASSESSMENTOF-FUNCTIONAL-PROPERTIES-AND-NUTRITIONAL-Asare-Agbemafle/647c623cf7d08c1b279c1dae149932b6575dc46b

[14] Santos CAF, Boiteux LS. Breeding biofortified cowpea lines for semi-arid tropical areas by combining higher seed protein and mineral levels. Genetics and Molecular Research.2013;12(4):6782-6789

[15] Welch RM, Graham RD. Breeding for micronutrients in staple food crops from a human nutrition perspective. Journal of Experimental Botany. 2004;55:353-364 
[16] Tarawali SA, Singh BB, Gupta SC. Cowpea as a key factor for a new approach to integrate crop-livestock systems research in dry savannas of West Africa. In: Challenges and opportunities for enhancing sustainable cowpea production. Proceedings of the world cowpea conference III held at the International Institute of Tropical Agriculture (IITA), Ibadan, Nigeria; 2002

[17] Hall A. Phenotyping cowpeas for adaptation to drought. Frontiers in Physiology. 2426;3, 2012:155

[18] Singh BB, Ehlers JD, Sharma B, Freire Filho FR. Recent progress in cowpea breeding.In: Fatokun CA, Tarawali SA, Singh BB, Kormawa PM, Tamò M, editors. Challenges and Opportunities for Enhancing Sustainable Cowpea Production. Ibadan: International institute of Tropical Agriculture; 2002. pp. 4-8

[19] Langyintuo AS, Lowenberg-DeBoer J, Faye M, Lamber D, Ibro G, et al. Cowpea supply and demand in West Africa. Field Crops Research. 2003;82:215-231

[20] Xiong H, Shi A, Mou B, Qin J, Motes D, Lu W, Wu D. Genetic diversity and population structure of cowpea (Vigna unguiculata L. Walp). PLoS One. 2016;11(8):e0160941

[21] Singh B. B., Ajeigbe H. A., Tarawali S. A., Fernandez-Rivera S., Abubakar M. (2003). Improving the production and utilization of cowpea as food and fodder. Field Crop Res. 84 169-177. 10.1016/S0378-4290(03)00148-5

[22] Kamara A. Y., Ewansiha S. U., Ajeigbe H. A., Okechukwu R., Tefera H., Boukar O., et al. (2012). "Improvement in grain and fodder yield of cowpea (Vigna unguiculata) varieties in the Sudan savannas of Nigeria over the past four decades," in Innovative Research Along the Cowpea Value Chain, eds Boukar O., Coulibaly O., Fatokun C. A., Lopez K., Tamo M. [Ibadan: International Institute of Tropical Agriculture (IITA)], 179-188.

[23] Bisikwa J., Kawooya R., Ssebuliba J. M., Ddungu S. P., Biruma M., Okello D. K. (2014). Effects of plant density on the performance of local and elite cowpea varieties in Eastern Uganda. Afr. J. Appl. Agric. Sci. Technol. $128-41$

[24] Ntibashirwa s. et Delaine b., 1989 : Diagnostic de la région naturelle de Kirimiro : ISABU Buja, 198p.

[25] Barantwaririje c., 1997 : Protocole de l'essai de correction des cultures en zinc. 5p.

[26]Agele SO*, Aiyelari OP, Famuwagun Band Oyewusi IK, 2018. Growth and Yield Adaptation of Cowpea Varieties Sown as Early- and Late-Rainy Season Crop in the Rainforest and Derived Savanna Agroecologies of South-West Nigeria. JOJ Horticulture and Arboriculture, Volume 1 Issue 5 - July 2018. DOI: 10.19080/JOJHA.2018.01.555575

[27] Sebetha E. T., Modi A. T., Owoeye L. G. (2015). Cowpea crude protein as affected by cropping system, site and nitrogen fertilization. J. Agric. Sci. 7 9752-9760 